www.jmscr.igmpublication.org

Impact Factor 5.84

Index Copernicus Value: 83.27

ISSN (e)-2347-176x ISSN (p) 2455-0450

crossref DOI: _https://dx.doi.org/10.18535/jmscr/v5i5.68

\title{
To Evaluate Use of Combined Modified Ripasa Scoring and Ultrasonography to Improve Diagnostic Accuracyin Acute Appendicitis
}

\author{
Author \\ Ravi Kumar \\ NBE New Delhi
}

\section{Introduction}

Acute appendicitis is a common cause of abdominal pain for which a prompt diagnosis and treatment is rewarded by a marked decrease in morbidity and mortality. Routine history and examination both remain the most effective and practical diagnostic modalities. ${ }^{1}$ Acute appendicitis is associated with raised TLC. It is raised in other inflammatory conditions also, making its role only supportive in the diagnosis of acute appendicitis. $^{2}$

There is limited role of Xrays in the diagnosis of acute appendicitis. It may rule out other causes of acute abdomen such as bowel perforation. Ultrasound is operator dependent and often misses or over diagnose the condition. ${ }^{3}$ CECT scan is the investigation of choice with high sensitivity and specificity for diagnosis but is expensive and not available at all centers particularly in developing countries, like India. ${ }^{4,5}$ Recent reports suggest that the indiscriminate use of CT scans may lead to detection of low grade appendicitis that would otherwise have resolved spontaneously. ${ }^{6,7,8}$

There has been a need of some scoring system that can overcome these problems, with good sensitivity and specificity and acceptable negative appendicectomieson exploration. One of the common scoring system is Alvarado system which is based on clinical and laboratory evidence of acute appendicitis, includes pain migrationto RIF, anorexia, nausea and vomiting, tenderness, rebound tenderness, fever, leucocytosis and shift of WBC to the left. ${ }^{9}$ The reported sensitivity and specificity for the Alvarado and the modified Alvarado scores range from $53 \%-88 \%$ and $75 \%-$ $80 \%$, respectively However, these scoring systems were developed in western countries, and several studies have reported very low sensitivity and specificity when these scores are applied to a population with a completely different ethnic origin and diet ${ }^{10,11}$.

In 2010 a new scoring system was developed at Department of Surgery, Raja Isteri Pengiran Anak Saleha Hospital, Brunei Darussalam and named after hospitals name, with calculated sensitivity and specificity of $88.46 \% \quad(95 \%$ confidence interval $83.94 \%-92.08 \%)$ and $66.67 \% \quad(95 \%$ Confidence interval $52.08 \%-79.24 \%$ ), respectively. $^{12}$

Hence this study is designed to evaluate the use of modified Ripasa score along with ultrasonography to diagnose acute appendicitis in preopera and accuracy of it will be evaluated by operative findings and postoperative histopathological examination. 


\section{Aim and Objectives}

1. To evaluate combined use of Modified ripasa score and ultrasonography in increasing diagnostic accuracy in cases of Acute appendicitis

2. To Compare the Combined score with operative findings and histopathology reports.

\section{Materials and Methods \\ Tools and techniques \\ Site of study}

Study will be conducted at Jaipur golden Hospital, 265 bedded muti- speciality tertiary care hospital.

\section{Type and Duration of Study -}

The study will be a prospective analysis of symptomatic patients with right iliac fossa pain, who have failed to improve even after sufficient conservative treatment and then presented in Jaipur golden hospital with complaints of right iliac foss pain. All cases treated upto December 2012 in this manner and qualifying the criteria will be included in this study

\section{Sample size and study population}

A minimum of sixty cases will be included in this study, with a minimum follow up of 3 months.

\section{Data collection tools and techniques}

Data will be gathered on clinical, radiological, histopathological and follow up examination according to the proforma attached. This will be tabulated; results and conclusion will be then obtained.

\section{Inclusion Criteria}

1. Age of patient 10-60 years. Either sex.

2. All Patients of suspected acute appendicitis

\section{Exclusion Criteria}

1. Age of patient not between 10-60 years.

2. Patients of blunt trauma abdomen with right iliac fossa pain

3. Patients with history of appendectomy

\section{Methodology}

For the purpose of this study we will follow patients who present with complaints of right iliac fossa pain at Jaipur Golden Hospital New Delhi. Clinical history with clinical examination, and radiological record of patient will be taken according to the proforma attached. Diagnosis will be confirmed by operative findings and post operative histopathological examination reports and usefulness of modified ripasa score with ultrasonography in diagnosis of acute appendicitis will be evaluated.

\section{Results and Observation}

In our study $36.7 \%$ of patients were in the age group of 21-30 years followed by $25 \%$ of patients who were in the age group of 10-20 years.

In our study $73.3 \%$ of patients were male suggesting incidence of acute appendicitis is more in male than female.

Migration of pain to right iliac fossa is seen in $36.7 \%$ of the patients in this study.

Nausea and vomiting is present in $66.7 \%$ of the patients in this study.

In our study loss of apetite is seen in only $26.7 \%$ of patients.

$56.7 \%$ of all patients in this study presented with duration of more than 48 hours while rest $43.3 \%$ patients presented within 48 hours of symptoms.

Right iliac fossa tenderness was present in $91.7 \%$ of patients in our study.

Abdominal guarding is present in $25 \%$ of all patients in this study.

Rebound tenderness is present in $66.7 \%$ patients of this study and there was no rebound tenderness in $33.3 \%$ of patients.

In our study rovsing sign was found to be positive in $51.7 \%$ andwas negative in $48.3 \%$ of all patients $55 \%$ of patients included in this study was complaining of fever at the time of presentation and $45 \%$ of patients was afebrile.

Total leucocyte count was raised in 42 out of 60 (70\%) of the patients in our study.

Urine analysis of patient was negative in $45 \%$ of all patients involved in this study. 


\begin{tabular}{|l|l|l|l|l|l|}
\hline Total & \multicolumn{4}{|l|}{ Histopathology Findings } & \multirow{2}{*}{ P value } \\
\cline { 2 - 5 } $\begin{array}{l}\text { Modified } \\
\text { Score }\end{array}$ & Positive & $\%$ & Negative & $\%$ & \\
\hline$>=7.25$ & 48 & $84.2 \%$ & 0 & $0 \%$ & \\
\hline$<7.25$ & 9 & $15.8 \%$ & 3 & $100 \%$ & \multirow{2}{*}{$0.006^{*}$} \\
\hline Total & 57 & $100 \%$ & 3 & $100 \%$ & \\
\hline
\end{tabular}

\begin{tabular}{|l|c|c|c|}
\hline STUDY & $\begin{array}{c}\text { Present } \\
\text { study } \\
\text { Threshold } \\
\text { score 7.25 }\end{array}$ & $\begin{array}{c}\text { Chong C F } \\
\text { et al } \\
\text { Threshold } \\
\text { score 7.5 }\end{array}$ & $\begin{array}{c}\text { Osama M } \\
\text { Khalil et al } \\
\text { Threshold } \\
\text { score 7.0 }\end{array}$ \\
\hline SENSITIVITY & $84.2 \%$ & $88.46 \%$ & $100 \%$ \\
\hline SPECIFICITY & $100 \%$ & $66.67 \%$ & $97 \%$ \\
\hline ACCURACY & $85 \%$ & $80.5 \%$ & $98 \%$ \\
\hline STUDY & $\begin{array}{c}\text { Present } \\
\text { study } \\
\text { Threshold } \\
\text { score 7.25 }\end{array}$ & $\begin{array}{c}\text { Chong C F } \\
\text { et al } \\
\text { Threshold } \\
\text { score 7.5 }\end{array}$ & $\begin{array}{c}\text { Osama M } \\
\text { Khalil et al } \\
\text { Threshold } \\
\text { score 7.0 }\end{array}$ \\
\hline SENSITIVITY & $84.2 \%$ & $88.46 \%$ & $100 \%$ \\
\hline SPECIFICITY & $100 \%$ & $66.67 \%$ & $97 \%$ \\
\hline ACCURACY & $85 \%$ & $80.5 \%$ & $98 \%$ \\
\hline
\end{tabular}

Ripasa score calculated on the basis of above clinical features and ROC curve is plotted, cut off threshold score was found to be 7.25 . $84.2 \%$ patients who were positive on histopathology had RIPASA SCORE >= 7.25 and $15.8 \%$ who were positive for acute appendicitis on histopathology had RIPASA score <7.25. No patient was negative on histopathology with score $>=7.25$ score. All Patients with histopathology negative had score <7.25.

According to our study Modified RIPASA score has sensitivity, specificity, PPV, NPV and accuracy of $84.2 \%, 100 \%, 100 \%, 25 \%$ and $85 \%$ respectively.

Ultrasound abdomen is done in all patients included in this study and $72 \%$ of patients were positive on ultrasound.

Histopathology is the gold standard for diagnosis in our study and 57 out of $60(95 \%)$ patients were found to be positive on histopathological examination.

In our study, ultrasound has sensitivity, specificity, PPV, NPV and accuracy of $70.2 \%$, $67 \%, 98 \%, 10.5 \%$ and $70 \%$ respectively.

On combining Modified RIPASA score and ultrasound, $98.2 \%$ were found positive and $1.8 \%$ patient was negative in all 57 patients who were positive on HPE. In 3 patients who were negative on HPE, $66.7 \%$ were negative on RIPASA+USG and $33.3 \%$ patients were positive on RIPASA +USG.

In our study Modified RIPASA and USG has sensitivity, specificity, PPV, NPV and accuracy of $98.2 \%, 66.7 \%, 98.2 \%, \quad 66.7 \%$ and $96.7 \%$ respectively.

\section{Conclusions}

1) Modified RIPASA score is an important tool for diagnosis of acute appendicitis with sensitivity of $84.2 \%$ as compared to RIPASA score study by Chong $\mathrm{C} \mathrm{F}$ et al with sensitivity of $88.46 \%$.

2) Modified RIPASA score is found to be more specific than RIPASA score by Chong C F et al.

3) Diagnostic accuracy of Modified RIPASA score is more $(85 \%)$ than RIPASA score $(80.5 \%)$.

4) ROC analysis depicts cutoff point of 7.25 for Modified RIPASA score for diagnosis with maximum sensitivity and specificity which is consistent with original cutoff of 7.5 .

5) 48 patients $(84.2 \%)$ with score $\geq 7.25$ were positive on HPE, while among 12 patients with score $<7.25,9$ were positive and 3 were negative on HPE.

6) Ultrasound is a good adjunct for diagnosis of acute appendicitis with sensitivity, specificity and diagnostic accuracy of $70.2 \%, 67 \%$, and $70.0 \%$ respectively in our study.

7) By adding USG with Modified RIPASA score sensitivity and diagnostic accuracy is increased from $84.2 \%$ and $85 \%$ to $98.2 \%$ and $96.7 \%$ respectively. 
8) By adding USG with Modified RIPASA score specificity is decreased from $100 \%$ to $66.7 \%$.

9) By adding USG with Modified RIPASA score PPV becomes $98.2 \%$ in compare with $100 \%$ of Modified RIPASA score, while NPV increased from $25 \%$ to $66.7 \%$.

10) Negative appendicectomy reduced to $5 \%$ by adding USG with Modified RIPASA score in compared with $16.3 \%$ in RIPASA score study by Chong $\mathrm{C} \mathrm{F}$ et al.

11) Modified RIPASA score with USG can successfully diagnose acute appendicitis with less negative appendicectomy rate and can be used in asian population for diagnosing acute appendicitis.

12) Among 3 HPE negative patient one was female of reproductive age group and two were male one of 58 years and second of 25 years of age.

13) Most of the patients $(83.4 \%=50)$ were in age group of 10-40 years with maximum incidence in 21-30 years of age.

14) Male were more affected with acute appendicitis with $73.3 \%$ of all patients ,well correlated with several studies.

15) There is paucity of studies that compares histopathological findings with score and USG findings,needs to be evaluated further by prospective studies.

\section{References}

1. Peterson MC, Holbrook JH, Hales D, Smith NL, Staker LV. Contributions of history, physical examination and laboratory investigations in making medical diagnosis, West J Med. 1922;156(2):163-5.

2. Lau WY, Ho YC, Chu KW, YeungC. Leucocyte count and neutrophil percentage in appendicectomy for suspected appendicitis. Aust N Z J Surg. 1989;59(5):395-8

3. Al-Ajerami Y. Sensitivity and specificity of ultrasound in the diagnosis of acute appendicitis. East Mediterr Health J.2012;18(1):66-9.

4. Krajewski S, Brown J, Phang PT, Raval M, Brown CJ.Impact of computed tomography of the abdomen on clinical outcomes in patient with right lower quadrant pain:a metaanalysis.Can J Surg. 2011;54(1):43-53.

5. Ozao-Choy j, Kim U, Vieux U,Menes TS. Incidental findings on computed tomography scans for acute appendicitis: Prevalence,costs and outcome. Am Surg. 2011;77:1502-9.

6. Petrosyan M,Estrada J, Chan S, Somers S, Yacoub WN, Kelso RL, Mason RJ. CT scan in patients with suspected appendicitis:clinical application for the acute care surgeon. Eur Surg Res. 2008;40 (2):211-9.

7. Anderson RE. Resolving appendicitis is common: further evidence. Ann Surg. 2008;247(3):553.

8. Livingston EH,Woodward WA, Sarosi GA, Haley RW. Disconnect between incidence of nonperforated and perforated appendicitis: implications for pathophysiology and management. Ann Surg. 2007;245(6):886-92.

9. Alvarado A. A practical score for the early diagnosis of acute appendicitis. Ann Emerg Med 1986; 15:557-64.

10. Patricia Lipford Abbit. Ultrasound: A Pattern Approach. Florida: University of Florida college of medicine; 1995 ; chapter 5; p182-83.

11. Paul A. Dubbins, Gastrointestinal tract and Peritoneum. In: Barry B. Goldberg ed. Textbook of abdominal ultrasound,Chapter 11:p252-253.

12. Chong C F, Adi M I W, Thien A, Suyoi A, Mackie A J, Tin A S, Tripathi S, Jaman N H,Tan K K, Kok K Y, Mathew V V, Paw O, Chua H B, Yapp S K; Development of the RIPASA score: a new appendicitis scoring system for the diagnosis of acute 
appendicitis, Singapore Med J 2010;51(3): 220-225.

13. Williams GR.Presidential address: A history of appendicitis. Ann Surg. 1983;197:495-506.

14. Toledo-pereyra LH. De Humani Corporis Fabrica surgical revolution. J Invest Surg. 2008;21(5):232-6.

15. Treves F. A series of cases of relapsing typhilitis treated byoperation. $\mathrm{Br} \mathrm{Med}$ J.1893;1(1686):835-7.

16. Fitz RH.Perforating inflammation of the vermiform appendix with special reference to its early diagnosis and treatment.Am J Med Sci. 1886;92:321-46.

17. Mc Burney C : Experience with early operative interference in cases of disease of the vermiform appendix. NY State Med J 1889;50:676.

18. Mc Burney C: The incision made in the abdominal wall in cases of appendicitis. Ann Surg 1894; 20:38.

19. Semm K: Endoscopic appendectomy. Endoscopy 1983; 15:59.

20. Bhattacharjee PK, Chowdhury T, Roy D. "Prospective evaluation of Modified Alvarado score for diagnosis of acute appendicitis." J Indian Med Assoc, May 2002; 100 (5): 310-1, 314.

21. Malik AA \& Wani NA."Continuing diagnostic challenge of acute appendicitis; evaluations through modified Alvarado score." Aust NZ J Surg,: July 1998; 68(7):504-5.

22. Kalan M. et Al. "Evaluation of the modified Alvarado score in the diagnosis of acute appendicitis, a prospective study". Ann R Coll Surg Engl 1994; 76:418-9.

23. Saidi HS, Chavda SK. "Use of a modified Alvarado score in the diagnosis of acute appendicitis." East Afr Med J,: August 2003; 80 (8): 411-4.

24. Lamparelli MJ, Hoque HM, Pogson CJ, and Ball AB. "A prospective evaluation of the combined use of the modified
Alvarado score with selective laproscopy in adult females in management of suspected appendicitis." Ann R Coll Surg Engl, May 2000; 82(3): 192-5.

25. Jeremiah C Healy. "Vermiform appendix". Chapter 78. In Grays anatomy - The anatomical basis of clinical practice, Susan Standring Elsevier Churchill Living Stone: 2005; (39):1189-90.

26. "The appendix". Chapter 5. Lee McGregror's Synopsis of surgical anatomy. G A G Decker, D J du Plessis ; Varghese publishing house ,Bristol; 1986; (12): 31- 42.

27. Wakeley, CPG. The position of the vermiform appendix as ascertained by an analysis of 10,000 cases. J Anat Physiol 1933;67:277-83.

28. James M Crawford. "Appendix”. Chapter 17 In Robbins and Cotran - Pathologic basis of disease. Kumar, Abass, Fansto;Philadelphia, Pensylvania. Elsevier:. 2004; (7): 870-71.

29. Addiss DG, Shaffer N, Fowler BS, et al: The epidemiology of appendicitis and appendectomy in the United States. Am J Epidemiol 1990;132: 910.

30. Korner H, Sondenaa K, Soreide JA, et al: Incidence of acute non perforated and perforated appendicitis: Age-specific and sex-specific analysis. World J Surg 1997;21: 313.

31. P Ronan O' Connel. "The Vermiform Appendix". Chapter 67. In Bailey and Love's - Short practice of surgery, Norman S Williams, Christopher J.K. Bulstrode, $\mathrm{P}$ Ronan O' Connel; London. Arnold: 25th edition. 2008; 1204-18.

32. Burkitt DP: The aetiology of appendicitis. Br J Surg 1971;58: 695.

33. Butler C: Surgical pathology of acute appendicitis.Hum Pathol 1981;12: 870.

34. Miranda R, Johnston AD, O'Leary JP: Incidental appendectomy: Frequency of 
pathologic abnormalities. Am Surg 1980;46:355.

35. Rautio M, Saxen H, Siitonen A, et al: Bacteriology of histopathologically defined appendicitis in children. Pediatr Infect Dis J 2000;19:1078.

36. Allo MD, Bennion RS, Kathir K, et al: Ticarcillin/clavulanate versus imipenem/cilastatin for the treatment of infections associated with gangrenous and perforated appendicitis. Am J Surg 1999; 65: 99.

37. Soffer D, Zait S, Klausner J, et al: Peritoneal cultures and antibiotic treatment in patients with perforated appendicitis. Eur J Surg 2001;167: 214.

38. Kokoska ER, Silen ML, Tracy TF Jr., et al: The impact of intraoperative culture on treatment and outcome in children with perforated appendicitis. J Pediatr Surg 1999;134: 749.

39. Mosdell DM, Morris DM, Fry DE: Peritoneal cultures and antibiotic therapy in pediatric perforated appendicitis. Am J Surg 1994;167: 313.

40. Bilik R, Burnvveit C, Shandling B: Is abdominal cavity culture of any value in appendicitis? Am J Surg 1998;175:267.

41. Murphy JB: Appendicitis with original report histories and analysis of one hundred and fifty-one laparotomies for that disease under personal observation. JAMA : 1894, (22):302-304.

42. Douglas S Smink, David I Soybel. "Appendix and Appendectomy" Chapter 21.In Manigot's abdominal operations, Michacel J Zinner, Stanely W Ashely McGraw Hill; 11th edition, 2007; 589-612.

43. Mangi AA, Berger DL. Stump appendicitis. Am Surg; 2000;66:739-741.

44. Wagner JM. Likelihood ratios to determine 'Does this patient have appendicitis?': Comment and clarification. JAMA; 1997;278:819-820.
45. Wagner JM, McKinney WP, Carpenter JL. Does this patient have appendicitis? JAMA; 1996;276: 1589-1594.

46. Gordon L. Telford, James R. Wallace. "Appendix" Chapter 13. In Surgery of elimentary tract, Shackelford. George D. Zuidema, Charles J. Yeo. W.B.Saunder's: 4(5) 2002; 180-189.

47. Thompson MM, Underwood MJ, Dookeran KA et al. Role of sequential leucocyte counts and C-reactive protein measurements in acute appendicitis. $\mathrm{Br} \mathbf{J}$ Surg; 1992;79: 822-824.

48. Wise SW, Labuski MR, Kasales CJ et al. Comparative assessment of CT and sonographic techniques for appendiceal imaging. AJR Am J Roentgenol; 2001;176: 933-941.

49. Teicher I, Landa B, Cohen M, Kabnick LS, Wise L.Scoring system to aid in the diagnosis of appendicitis. Ann Surg.1983;198:753-9.

50. Jawaid A, Asad A, Motiei, Munir A, Bhutto E, ChoudhryH et.al.Clinical Scoring system:a valuable tool for decision making in case of acute appendicitis. J Pak Med Assoc. 1999;49:254-9

51. Chan MY, Teo BS, Ng BL. TheAlvarado score and acute appendicitis. Ann Acad med Singapore. 2001;30:510-2.

52. Al-Hashmey AM, Seleem MI. Appraisal of the Modified Alvarado score for acute appendicitis in adults. Saudi Med J. 2004;25:1229-31.

53. Khan I, Ur Rehman A. Application of Alvarado Scoring in diagnosis of acute appendicitis . J Ayub Med Coll Abootabaad. 2005;17:41-4.

54. Jang SO, Kim BS, Moon DJ. Application of Alvarado score in patients with suspected appendicitis. Korean J Gastroenterol. 2008;52:27-31.

55. Baidya N, Rodrigues G, Rao A, Khan SA,: Evaluation of Alvarado score in acute 
appendicitis: a prospective study. The Internet Journal of Surgery. 2007;9:1-3.

56. Dey S, Mohanta PK, Baruah AK, Kharga B, Bhutia KL, Singh VK: Alvarado scoring in Acute appendicitis-a clinicopathological correlation. Indian $\mathrm{J}$ Surg. 2010;72:290-3.

57. Eskelin M, Ikonen J, Lipponen P. Sex specific diagnostic scores for acute appendicitis. Scand J Gastroenterol. 1994;29:59-66.

58. Sitter H, Hoffmann S, Hassan I, Zielke A,. Diagnostic Score in appendicitis. Validation of a diagnostic score (Eskelinen score) in patients in whom acute appendicitis is suspected. Langenbecks Arch Surg. 2004; 389:213-8.

59. Lintula H, Pesonen E, Kokki H, Vanamo K, Eskelinen M. A diagnostic score for children with suspected appendicitis. Langenbecks Arch Surg. 2005;390:164-70.

60. Lintula H, Kokki H, Kettunen R, Eskelinen M.,. Appendicitis score for children with suspected appendicitis. A randomized clinical trial. Langenbecks Arch Surg. 2009;394:999-1004.

61. Lintula H, Kokki H, Pulkkinen J, Kettunen R, Grohn O, Eskelinen M. Diagnostic Score in acute appendicitis. Validation of a diagnostic score (Lintula Score) for adults with suspected appendicitis.Langenbecks Arch sSurg. 2010;395:495-500.

62. Anderson M,Anderson RE.The Appendicitis Inflammatory Response score: A tool for the acute appendicitis that outperforms the ALVARADO Score. Wolrd J Surg. 2008;32:1843-9.

63. Chong CF, Thien A,Mackie AJ, Tin AS, Tripathi S, Ahmed MA, Tan LT, Ang SH, Telisinghe PU,Copmarison of RIPASA and Alvarado scores for the diagnosis of acute appendicitis. Singapore Med J. 2011;52 (5):340-5.

64. Flum DR, Morris A, Koepsell T, Dellinder $\mathrm{EP}$, has misdiagnosis of appendicitis decreased overtime? A population based analysis. JAMA 2001;286:1748-53.

65. Witoo k,Wipawee S, Ajjana k, Thammasorn P. Accuracy of RIPASA and modified RIPASA score comparing with Alvarado score for diagnosis of acute appendicitis and complications of acute appendicitis.A cross sectional diagnostic study.Thialnd . Digital journals. Org; 2011.

66. Osama MK. Using of the modified RIPASA score in diagnosis of acute appendicitis to decrease use of a abdominal computed tomography. Egyptian Journal of surgery 2013; vol.32(2):86-90.

67. Abu-Yousuf MM, Bleicher JJ, Maher JW et al. High resolution sonography of acute appendicitis. AJR 1987;149:53-8.

68. Grace S, Rozyeki. Surgeon performed ultrasound: Its use in clinical practice. Surg Clin North Am 1998;78:179-217.

69. Jeffrey RB, Laing FC, Townsend RR. Acute appendicitis:Sonographic criteria based on 250 cases. Radiology 1988; 167:327-329.

70. John H, neff U, Kelman M(1993) Appendicitis Diagnosis today: clinical and ultrasonic deductions. World J Surg 17:243-49.

71. Stephens PL, Mazzucco JJ, comparison of ultrasound and the Alvarado score for diagnosis acute appendicitis.Conn Med 1999;63(3):137-40.

72. Fujii Y, Hata, Futagami K, Hamada T. Ultrasonography improves diagnostic accuracy of acute appendicitisand provides cost savings to hospitals in japan. $\mathbf{J}$ Ultrasound Med;19:409-14.

73. Arnbjornsson E, Bengmark $\mathrm{S}$ :Role of obstruction in pathogenesis of acute appendicitis. Am J Surg. 1984;147:390-2.

74. Sisson RG, AhlvinRC, Harlow MC.Superficial mucosal ulceration and the pathogenesis of acute appendicitis.Am $\mathrm{J}$ Surg.1971;122:378-80. 
75. Coggan D, Barker DJ, Cruddas M, oliver $\mathrm{H}$. Housing and appendicitis in anglesay. $\mathbf{J}$ Epidemiol Community health.1991; 45:244-6.

76. Larner AJ. The aetiology of appendicitis. Br J Hosp Med.1988;39:540-2.

77. Aravindan KP.Eosinophils in acute appendicitis: Possible significance. Indian J Pathol Microbiol. 1997;40:491-8.

78. Jones MW, Paterson AJ. The correlation between gross appearance of appendix at appendicectomy and histopathological examination. Annals of the Royal college of Surgeons of Engl. 1988;70:93-4.

79. Shah RC, MehtaKN, Julundhwala JM. Tuberculosis of Appendix. J Indian Med Assoc. 1967:49:138-40.

80. Dymock RB.Pathological changes in the appendix: a review of 1000 cases. Pathology.1977,9:331-9.

81. Mittal VK, Khanna SK, Gupta NM, Aikat M. Isolated tuberculosis of the appendix. Ann Surg. 1975,41:172-4.

82. Bhasin V, Chopra P, Kapur BM. Acute tubercular appendicitis. IntSurg.1977; 62:563-4. 